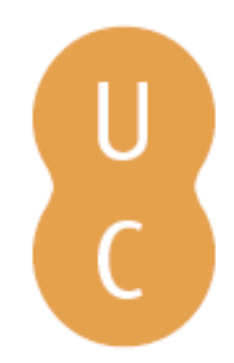

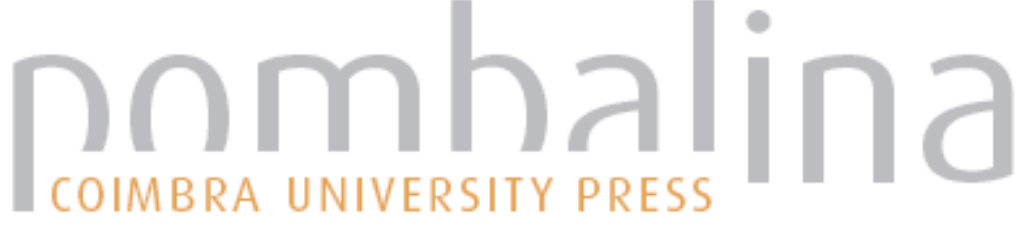

\section{Perspectivas de evolução do Direito da Família em Portugal}

Autor(es): $\quad$ Pinheiro, Jorge Duarte

Publicado por: Imprensa da Universidade de Coimbra

URL

persistente:

URI:http://hdl.handle.net/10316.2/38889

DOI:

DOI:http://dx.doi.org/10.14195/978-989-26-1113-6_11

Accessed : $\quad$ 26-Apr-2023 10:04:03

A navegação consulta e descarregamento dos títulos inseridos nas Bibliotecas Digitais UC Digitalis, UC Pombalina e UC Impactum, pressupõem a aceitação plena e sem reservas dos Termos e Condições de Uso destas Bibliotecas Digitais, disponíveis em https://digitalis.uc.pt/pt-pt/termos.

Conforme exposto nos referidos Termos e Condições de Uso, o descarregamento de títulos de acesso restrito requer uma licença válida de autorização devendo o utilizador aceder ao(s) documento(s) a partir de um endereço de IP da instituição detentora da supramencionada licença.

Ao utilizador é apenas permitido o descarregamento para uso pessoal, pelo que o emprego do(s) título(s) descarregado(s) para outro fim, designadamente comercial, carece de autorização do respetivo autor ou editor da obra.

Na medida em que todas as obras da UC Digitalis se encontram protegidas pelo Código do Direito de Autor e Direitos Conexos e demais legislação aplicável, toda a cópia, parcial ou total, deste documento, nos casos em que é legalmente admitida, deverá conter ou fazer-se acompanhar por este aviso.

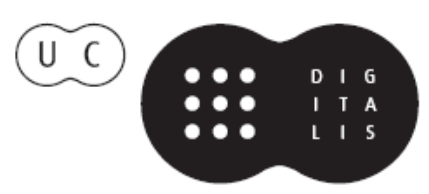




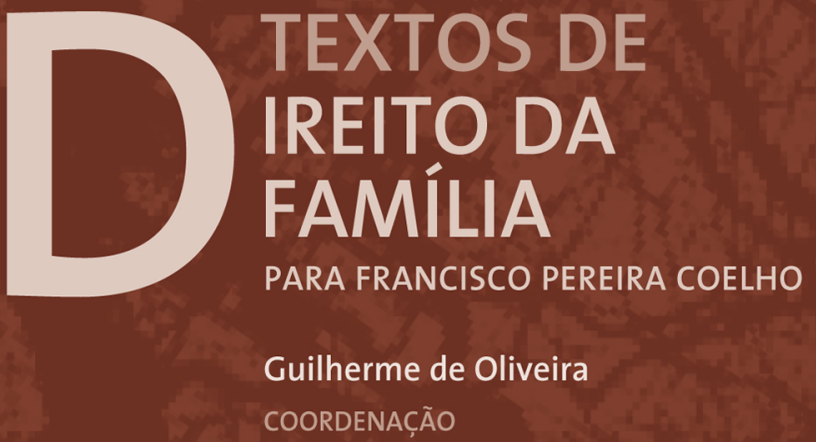




\title{
PERSPECTIVAS DE EVOLUÇÃO DO DIREITO DA FAMÍLA EM PORTUGAL ${ }^{1}$
}

\begin{abstract}
Jorge Duarte Pinheiro
Doutor em Direito e professor associado em regime de tempo indeterminado, ou "tenure", da Faculdade de Direito da Universidade de Lisboa
\end{abstract}

\section{Sumário}

1. As questões. 2. A situação há cinquenta anos. 3. A situação actual. 4. O peso da tradição. 5. Mudanças em que sentido?

\section{As questões}

O Direito não está imune à influência dos fenómenos sociais, que, aliás, visa modelar. E o Direito da Família participa das características do todo a que pertence. No entanto, a sua permeabilidade à realidade social é superior à da generalidade dos sectores do Direito $^{2}$. De tal modo superior que quase parece ser um sensor da

\footnotetext{
1 Texto concluído em 7 de Março de 2015.

2 Cf. Francisco Pereira Coelho/Guilherme De Oliveira, Curso de Direito da Família, vol. I, Introdução. Direito Matrimonial, $4^{a}$ ed., Coimbra, Coimbra Editora, pp. 147-149; JORGE DUARTE PINHeIro, O ensino do Direito da Família Contemporâneo, Lisboa, AAFDL, 2008, pp. 29-31 (afirmando-se, nomeadamente, que "a sua ligação estreita a aspectos primordiais da existência humana torna o Direito da Família particularmente vulnerável aos valores que circulam na comunidade").
} 
geografia e da cronologia social, das concepções de vida, políticas e apolíticas, religiosas e laicas.

Por isso, é arriscado falar sobre o Direito da Família de um modo não localizado, como se, por exemplo, não houvesse distinção quanto ao que é este ramo de Direito entre Portugal e a Arábia Saudita.

Assim sendo, o texto ocupa-se somente de Portugal, embora não se possa negar a actual afinidade entre o nosso regime jusfamiliar e o de outros países ocidentais ${ }^{3}$.

Ora, esta amostra territorialmente circunscrita do mundo não deixa de ser rica, expressiva do espaço euroamericano. A doutrina contemporânea deste espaço, incluindo o rectângulo lusitano, tem aguda percepção das transformações que ocorreram ao longo de poucas décadas ${ }^{4}$. Já não é preciso um longo intervalo temporal de análise para se estabelecerem contrastes. Claro que é interessante aludir ao Direito Romano ou à Idade Média, mas o traçado de uma grande fractura está logo ao alcance de um estudo exclusivamente dedicado ao século XX, que observe o antes e o depois dos anos 60-705.

$\mathrm{O}$ cidadão comum e a comunicação social estão atentos às mudanças familiares, que detectam, discutem, divulgam, hiperbolizam, antecipam.

3 Cf. Guilherme De Oliveira, "Um Direito da Família Europeu? (Play it again and again...Europe)", texto publicado na obra do mesmo autor, Temas de Direito da Família, $2^{a}$ ed., Coimbra, Coimbra Editora, 2001, p. 319 e s.; JORGE DUARTE PINHEIRO, O Direito da Família Contemporâneo. Lições, $4^{\text {a }}$ ed., Lisboa, AAFDL, 2013, pp. 84-85 ("A tendência para importar soluções provenientes de ordenamentos estrangeiros, associada a uma certa homogeneidade das várias sociedades nacionais, levou já à formação, quase espontânea, de um núcleo ocidental comum de Direito da Família").

${ }^{4}$ Cf., por todos, Guilherme De Oliveira, "Transformações do Direito da Família", em AA.VV., Comemorações dos 35 anos do Código Civil e dos 25 anos da Reforma de 1977, vol. I, Direito da Família e das Sucessões, Coimbra, Coimbra Editora, p. 763 e $s$.

5 Cf. JORGE DUARTE PINHEIRO, O ensino do Direito da Família Contemporâneo cit., p. 32 e s., p. 47 e s. (antes de 1960-1970, a Europa e a América vivem num período de monismo jusfamiliar, enquanto a partir dos finais da década de 60 decorrem reformas legislativas flexibilizadoras que irão consagrar um modelo pluralista). 
O académico clássico do Direito, esse, prefere um cenário mais estável, que lhe permita calmamente formular construções duradouras. Um cenário que lhe confira um sentimento de trabalho prestado e concluído ou de teorização imortal. Para ele, o Direito da Família é um terreno amaldiçoado e minado, em que uma tese não resiste um ano, em que um artigo ou livro rapidamente se desactualiza.

Todavia, há também aquele académico que não se atemoriza, ou até aprecia, o perfil dinâmico deste ramo, repleto de novidades e contradições, campo fértil para paixões e para a descoberta de concepções existenciais do próprio e do outro. Longe vão os tempos em que o estudioso apresentava opinião incisiva e peremptória sobre um tema de Direito da Família perante trinta pessoas que abanavam a cabeça, em sinal de concordância!

Muito mudou, pois. As pessoas, o seu entendimento de família e, claro, a disciplina normativa das ligações familiares.

Sim, mas importa ser concreto. O que mudou em cinquenta anos no Direito civil da Família ${ }^{6}$ nuclear, o que se mantém e o que ainda pode mudar nos próximos anos?

As próximas páginas ocupam-se precisamente destas questões privilegiando o domínio do regime jurídico das uniões íntimas. Tendo sido já objecto de outro trabalho, a evolução do regime jurídico da filiação será considerada aqui com menor desenvolvimento ${ }^{7}$.

${ }^{6}$ O Direito da Família em sentido amplo compreende o Direito civil e o Direito não civil da Família (cf. JORGE DUARTE PINHEIRO, O Direito da Família Contemporâneo cit., p. 42): o primeiro, Direito da Família em sentido restrito abrange as normas que se incluem no livro IV do Código Civil e as normas que, situadas noutros locais, estabeleçam uma disciplina análoga ou complementar; o Direito não civil da Família agrega as demais normas que respeitam à família e que se enquadram formalmente, por exemplo, no Direito Penal, no Direito Fiscal, no Direito da Função Pública e da Segurança Social e no Direito do Trabalho.

7 Cf. JORGE DUARTE PINHEIRO, "Novos pais e novos filhos: sobre a multiplicidade no Direito da Família e das Crianças", em AA.VV., I Congresso Luso-Brasileiro de Direito, Coimbra, Almedina, 2014, pp. 173-182. Não se trata, portanto, de uma atitude que desvaloriza o Direito da Filiação perante o Direito Matrimonial. O autor sempre sustentou que a relevância da primeira grande divisão do Direito da Família 


\section{A situação há cinquenta anos}

I. Há cinquenta anos, em 1965, altura em que ainda vigorava o Código Civil Português de 1867 e a legislação republicana relativa à família, o casamento só podia ser celebrado entre pessoas de sexo oposto, perante sacerdote da Igreja Católica ou oficial do registo civil, e implicava a subordinação da mulher ao marido. A união de facto não era regulada, sendo socialmente reprovada.

$O$ artigo $1^{\circ}$ do Decreto $n^{\circ} 1$, de 25 de Dezembro de 1910, definia o casamento como "um contrato celebrado entre duas pessoas de sexo diferente, com o fim de constituírem legitimamente família".

Além de consagrar o requisito da heterossexualidade, esta disposição marginalizava implicitamente a união de facto, quando associava casamento e fim de constituir legitimamente família.

Enquanto o artigo $1057^{\circ}$ do primeiro Código Civil português, na redacção do Decreto n ${ }^{\circ} 19.126$, de 16 de Dezembro de 1930, previa que o casamento fosse celebrado "perante o oficial do registo civil, com as condições e pela forma estabelecida na lei civil", o artigo $2^{\circ}$ do Decreto $\mathrm{n}^{\circ}$ 30.615, de 25 de Julho de 1940, atribuía também relevância estatal ao casamento contraído em conformidade com o Direito Canónico desde que o respectivo assento estivesse transcrito no registo civil.

Embora ao regular os efeitos do casamento, a lei começasse por proclamar a igualdade como base da sociedade conjugal e por sujeitar ambos os cônjuges às obrigações de guardar mutuamente fidelidade conjugal, de viver juntos, de socorrer-se e ajudar-se reciprocamente (artigo $38^{\circ}$ e primeira parte do artigo $39^{\circ}$ do Decreto $\mathrm{n}^{\circ}$ 1, de 25 de Dezembro de 1910), rapidamente se vislumbrava uma acentuada diferenciação de estatutos em função do sexo. Incumbia

não deve ser inferior à da segunda, com os consequentes reflexos na repartição do tempo lectivo global disponível (cf. O ensino do Direito da Família Contemporâneo cit., p. 297, e O Direito da Família Contemporâneo cit., p. 125). 
ao marido "especialmente, a obrigação de defender a pessoa e os bens da mulher e dos filhos, e à mulher, principalmente o governo doméstico e uma assistência moral tendente a fortalecer e a aperfeiçoar a unidade familiar" (artigo 39 ${ }^{\circ}$ do Decreto $\mathrm{n}^{\circ} 1$, de 25 de Dezembro de 1910); a mulher devia, em regra, adoptar a residência do marido (artigo $40^{\circ}$ do Decreto $\mathrm{n}^{\circ} 1$, de 25 de Dezembro de 1910); e a este pertencia a administração de todos os bens do casal (artigo $1189^{\circ}$ do Código Civil de 1867).

$\mathrm{Na}$ mesma época, a possibilidade de divórcio era negada aos que tivessem celebrado casamento católico e concedida, dentro de certas condições, aos que tivessem celebrado casamento civil.

De facto, o artigo XXIV da Concordata entre Portugal e a Santa Sé, de 7 de Maio de 1940, determinava:

"Em harmonia com as propriedades essenciais do casamento católico, entende-se que pelo próprio facto da celebração do casamento canónico, os cônjuges renunciarão à faculdade civil de requererem o divórcio, que por isso não poderá ser aplicado pelos tribunais civis aos casamentos católicos".

Por conseguinte, a Lei do Divórcio, aprovada por Decreto de 3 de Novembro de 1910, regulava somente a dissolução do casamento civil. Em 1965, no caso de casamento civil, era permitido o divórcio, quer litigioso quer por mútuo consentimento (artigo $3^{\circ}$ da Lei do Divórcio). A obtenção de divórcio litigioso, pedido por um só dos cônjuges, dependia do preenchimento de uma das causas taxativamente enunciadas no artigo $4^{\circ}$ da referida Lei do Divórcio ${ }^{8}$. O

8 O corpo do artigo $4^{\circ}$ indicava o seguinte elenco de causas de divórcio:

" $\left.1^{\circ}\right)$ O adultério da mulher;

" $2^{\circ}$ ) O adultério do marido;

“ $3^{\circ}$ ) A condenação definitiva de um dos cônjuges a qualquer das penas maiores fixas dos artigos $55^{\circ}$ a $57^{\circ}$ do Código Penal;

" $\left.4^{\circ}\right)$ As sevícias e as injúrias graves; 
divórcio por mútuo consentimento, pedido por ambos os cônjuges conjuntamente, pressupunha que os dois requerentes tivessem idade superior a 25 anos e estivessem casados há mais de dois anos (artigo $35^{\circ}$ da Lei do Divórcio).

II. Há cinquenta anos, podia ser pai quem tivesse relações sexuais com pessoa de sexo oposto; a adopção não era admitida; e a procriação medicamente assistida não era atendível para efeitos de estabelecimento da filiação.

Abolido pelo Código Civil de 1867, o instituto da adopção viria a ser restaurado pelo Código Civil de 1966. Em contrapartida, a versão originária do segundo Código Civil português continuaria a não fazer concessões à procriação medicamente assistida 9 .

Podendo a qualidade jurídica de pai caber àquele que tivesse relações sexuais com pessoa de sexo oposto, isso não significa que fosse indiferente o vínculo entre os progenitores: em 1965, deviam ser pais o homem e a mulher casados um com o outro. Os filhos nascidos fora do casamento eram tidos como ilegítimos, estando sujeitos a um estatuto social e jurídico desfavorável ${ }^{10}$.

" $\left.5^{\circ}\right) \mathrm{O}$ abandono completo do domicílio conjugal por tempo não inferior a três anos;

" $6^{\circ}$ ) A ausência, sem que do ausente haja notícias, por tempo não inferior a três anos;

" $7^{\circ}$ ) A loucura incurável quando decorridos, pelo menos, três anos sobre a sua verificação por sentença passada em julgado, nos termos dos artigos $419^{\circ}$ e seguintes do Código de Processo Civil;

" $8^{\circ}$ ) A separação de facto, livremente consentida, por dez anos consecutivos, qualquer que seja o motivo da separação;

" $9^{\circ}$ ) O vício inveterado do jogo de fortuna ou de azar;

" $10^{\circ}$ ) A doença contagiosa reconhecida como incurável, ou uma doença incurável que importe aberração sexual."

${ }^{9}$ Se o primeiro Código Civil não continha referências à procriação medicamente assistida, o artigo $1799^{\circ}$ do segundo Código, na versão originária, dispunha: "A fecundação artificial não pode ser invocada para estabelecer a paternidade do filho procriado por meio dela nem para impugnar a paternidade presumida por lei".

10 Por exemplo, em concurso com filho nascido do casamento, o chamado filho ilegítimo beneficiava de uma quota menor na herança do pai (cf. $\operatorname{artigos~} 1785^{\circ} \mathrm{e}$ $1991^{\circ}$ do Código Civil de 1867). 
Na mesma época, a relação de filiação apresentava um perfil nitidamente hierarquizado. Os pais eram titulares do poder paternal, definido como um complexo de direitos que incluía reger as pessoas dos filhos menores, protegê-los e administrar os bens deles (artigo $137^{\circ}$ do Código Civil de 1867). E durante a menoridade, que só terminava aos 21 anos de idade (artigo $97^{\circ}$ do Código Civil de 1867), os filhos deviam cumprir todas as determinações dos pais que não fossem ilícitas (artigo $142^{\circ}$ do Código Civil de 1867).

Predominava uma imagem autoritária e distante do pai, ao qual geralmente se concedia o uso de todos os meios que estivessem ao seu alcance para ser obedecido ${ }^{11}$.

$\mathrm{Na}$ hipótese de os progenitores estarem casados entre si, o artigo $138^{\circ}$ do Código Civil de 1867 previa um exercício heterogéneo do poder paternal:

"As mães participam do poder paternal e devem ser ouvidas em tudo o que diz respeito aos interesses dos filhos, mas é ao pai que especialmente compete durante o matrimónio, como chefe da família, dirigir, representar e defender seus filhos menores, tanto em juízo, como fora dele."

\section{A situação actual}

I. Hoje, o casamento é contraído entre homem e mulher, homem e homem, mulher e mulher; pode ser celebrado por forma laica, católica ou de outra religião; e cria uma relação entre iguais, sem um "chefe".

${ }^{11}$ Incluindo-se a possibilidade de obter, junto de autoridade judicial, a prisão do filho "desobediente e incorrigível" em casa de correcção por período não superior a trinta dias e de fazer cessar a detenção previamente ordenada (cf. artigo $143^{\circ}$ do Código Civil de 1867). 
O artigo $1577^{\circ}$ do Código Civil de 1966 , na redacção da Lei $\mathrm{n}^{\circ}$ 9/2010, de 31 de Maio, define o casamento como "o contrato celebrado entre duas pessoas que pretendem constituir família, mediante uma plena comunhão de vida, nos termos das disposições deste Código".

A diversidade de sexo deixou de ser requisito do casamento, tendo sido revogada a alínea e) do artigo $1628^{\circ}$, que estabelecia a inexistência jurídica do casamento contraído entre pessoas do mesmo sexo ${ }^{12}$.

Sendo agora permitido o casamento entre pessoas do mesmo sexo, o respectivo regime coincide com o do casamento entre pessoas de sexo diferente, salvo em matéria de filiação ${ }^{13}$.

No entanto, só é expressamente admitido o casamento civil entre pessoas do mesmo sexo (cf. artigo $1^{\circ}$ da Lei $\mathrm{n}^{\circ}$ 9/2010, de 31 de Maio), mais precisamente o casamento civil sob forma civil ou laica. A heterossexualidade subsiste para a outra forma desta mesma modalidade de casamento e para o casamento católico.

$\mathrm{O}$ artigo $1587^{\circ}$ do Código Civil de 1966 prevê duas modalidades de casamento, católico e civil.

Apesar de ser reconhecido pelo Direito Civil, o casamento católico é regido em matéria de validade por normas de Direito Canónico

${ }^{12}$ A mudança foi precedida de apreciação do Tribunal Constitucional, que não detectou qualquer incompatibilidade entre o alargamento da faculdade de casar e a Constituição portuguesa de 1976. Na perspectiva deste tribunal, o texto fundamental não impõe nem proíbe o casamento entre pessoas do mesmo sexo (cf. acórdãos $\mathrm{n}^{\circ} \mathrm{s}$ 359/2009, de 09/07/2009, e 121/2010, de 08/04/2010, disponíveis em http://www. tribunalconstitucional.pt).

13 É o que decorre do artigo $5^{\circ}$ da Lei $n^{\circ}$ 9/2010, de 31 de Maio, que exige que "todas as disposições legais relativas ao casamento e aos seus efeitos" sejam interpretadas à luz da mesma lei, "independentemente do género dos cônjuges, sem prejuízo do disposto no artigo $3^{\circ}$ ". Este artigo $3^{\circ}$ ocupa-se da adopção por pessoas casadas com cônjuge do mesmo sexo. Ao admitir o casamento entre pessoas do mesmo sexo, a lei portuguesa não lhe fixou uma disciplina específica de eficácia, pelo que a ele se entende extensível a totalidade da disciplina preexistente para o casamento entre pessoas de sexo diferente. 
(cf. artigo $1625^{\circ}$ do Código Civil de 1966). Ora, o Direito Canónico não aceita o casamento entre pessoas do mesmo sexo.

Com a Lei $\mathrm{n}^{\circ}$ 16/2001, de 22 de Junho (Lei da Liberdade Religiosa), o casamento civil, que, desde a entrada de vigor do Código Civil de 1867, comportava uma única forma de casamento, sendo celebrado perante funcionário do registo civil, passou a incluir outra forma, o casamento civil por forma religiosa.

O casamento civil por forma religiosa, ou casamento religioso não católico, é celebrado perante o ministro do culto de uma igreja ou comunidade religiosa radicada no País (cf. artigo $19^{\circ}, \mathrm{n}^{\circ} 1$, da Lei da Liberdade Religiosa). O ritual da cerimónia é definido pelas regras da igreja ou comunidade religiosa em causa, que não contemplam o casamento entre pessoas do mesmo sexo.

O casamento produz os mesmos efeitos, independentemente de ter sido celebrado entre pessoas de sexo diferente ou do mesmo sexo e de qual tenha sido a modalidade e a forma seguidas (católico ou civil, civil por forma civil ou civil por forma religiosa).

Tais efeitos são idênticos para os dois cônjuges, ainda que se trate de casamento heterossexual. Neste sentido, importa invocar várias normas do Código Civil de 1966, na redacção resultante da Reforma do Código Civil, aprovada pelo Decreto-Lei no 496/77, de 25 de Novembro: o artigo $1672^{\circ}$, ao estabelecer que os cônjuges estão reciprocamente vinculados pelos deveres de respeito, fidelidade, cooperação e assistência; o artigo $1671^{\circ}, \mathrm{n}^{\circ} 1$, que, ao determinar que o casamento assenta na igualdade de direitos e deveres dos cônjuges, afasta uma concretização dos deveres conjugais variável em função do género; o artigo $1671^{\circ}, \mathrm{n}^{\circ} 2$, que confia a direcção da família a ambos os cônjuges, pondo fim ao poder marital; o artigo $1673^{\circ}$, que impõe a fixação da residência da família por acordo dos cônjuges; o artigo $1677^{\circ}$-D, prevendo que cada um dos cônjuges pode exercer qualquer profissão ou actividade sem o consentimento do outro. Por fim, o artigo $1678^{\circ}$, que não faz depender a administração 
dos bens do casal do sexo dos cônjuges: em regra, cada um deles tem a administração dos seus bens próprios e legitimidade para a administração ordinária dos bens comuns, enquanto a administração extraordinárias desta categoria de bens só pode ser praticada com o consentimento de ambos. De assinalar que, após 1977, o texto do Código não procede a uma pré-fixação de papéis dentro do $\operatorname{lar}^{14}$.

Actualmente, qualquer casamento, católico ou civil, é susceptível de ser dissolvido por divórcio. Em 15 de Fevereiro de 1975 foi assinado o Protocolo Adicional à Concordata entre Portugal e a Santa Sé de 1940, cujo artigo I libertou o nosso País de um compromisso internacional que o vinculava a negar o divórcio àqueles que tivessem celebrado casamento católico depois de 1 de Agosto de 1940. Na sequência deste acto, o Decreto-Lei ${ }^{\circ}$ 261/75, de 27 de Maio, revogou a versão originária do artigo $1790^{\circ}$ do Código Civil de $1966^{15}$, concedendo a faculdade de divórcio também aos que tivessem contraído casamento católico em qualquer momento.

Outra evolução digna de nota respeita aos pressupostos menos exigentes em matéria de divórcio. A (re)abertura ao divórcio iniciou-se com o mencionado Decreto-Lei ${ }^{\circ}$ 261/75, de 27 de Maio, tendo culminado com a Lei $\mathrm{n}^{\circ} 61 / 2008$, de 31 de Outubro, a que se deve a regulamentação do divórcio em vigor ${ }^{16}$.

${ }^{14} \mathrm{Na}$ versão originária do artigo $1677^{\circ}, \mathrm{n}^{\circ} 1$, do Código Civil de 1966 , lia-se que "pertence à mulher, durante a vida em comum, o governo doméstico, conforme os usos e a condição dos cônjuges".

15 Sob a epígrafe "Casamentos indissolúveis por divórcio", o antigo artigo $1790^{\circ}$ dizia:

"Não podem dissolver-se por divórcio os casamentos católicos celebrados desde 1 de Agosto de 1940, nem tão-pouco os casamentos civis quando, a partir dessa data, tenha sido celebrado o casamento católico entre os mesmos cônjuges".

16 O diploma de 1975 restaurou a possibilidade de divórcio por mútuo consentimento, abolida pela versão originária do Código Civil de 1966, e colocou a separação de facto livremente consentida por cinco anos entre as causas de divórcio litigioso. No campo das causas de divórcio litigioso, o Decreto-Lei n ${ }^{\circ}$ 561/76, de 17 de Junho, aumentou de cinco para seis anos o prazo de separação de facto, mas eliminou a exigência de que esta fosse livremente consentida. O Decreto-Lei ${ }^{\circ} 605 / 76$, de 24 de Julho, baixou de três para dois anos o prazo de duração do casamento que era 
Após a lei de 2008, o sistema de divórcio que se extrai do Código Civil é o seguinte: contraposição entre divórcio por mútuo consentimento e divórcio litigioso ou sem o consentimento de um dos cônjuges (artigo $1773^{\circ}$ ); possibilidade de divórcio por mútuo consentimento sem condições mínimas quanto à idade dos contraentes ou à duração do casamento (artigos $1775^{\circ}$ e $1778^{\circ}$-A); previsão expressa da separação de facto por um ano consecutivo no elenco de fundamentos de divórcio litigioso (artigo $1781^{\circ}$, alínea a)); inclusão em tal elenco, após referência à alteração das faculdades mentais e da ausência do outro cônjuge, de "quaisquer outros factos que, independentemente da culpa dos cônjuges, mostrem a ruptura definitiva do casamento" (artigo 1781 ${ }^{\circ}$, alínea d)), o que, por um lado, corresponde a uma cláusula geral que permite o alargamento do universo de hipóteses de divórcio, em contraste com um sistema que chegou a estar assente numa enumeração taxativa (contida no artigo $4^{\circ}$ da Lei do Divórcio de 1910), e que, por outro lado, retira importância à culpa no quadro da dissolução do casamento ${ }^{17}$.

II. A situação normativa presente da união de facto é diferente daquela que se verificava há 50 anos.

A noção legal de casamento em vigor já não atribui a este instituto uma finalidade de constituição legítima de família. A eliminação do advérbio legitimamente que figurou até 1977 no artigo $1577^{\circ}$

necessário para requerer o divórcio por mútuo consentimento. Se bem que tivesse retomado o prazo de três para a duração do casamento, o Decreto-Lei $n^{\circ} 496 / 77$, de 25 de Novembro, que aprovou a Reforma do Código Civil, pôs fim ao requisito de uma idade mínima dos cônjuges para efeitos de divórcio por mútuo consentimento ( 25 anos, por força do artigo $1786^{\circ}$ do Código Civil de 1966, na versão originária). A Lei $\mathrm{n}^{\circ}$ 47/98, de 10 de Agosto, consagrou a possibilidade de se requerer o divórcio por mútuo consentimento a todo o tempo, afastando assim a imposição de um período mínimo de casamento, e reduziu de seis para três anos o tempo mínimo da separação de facto relevante enquanto causa de divórcio.

${ }^{17}$ Culpa que esteve presente ao longo de quase 100 anos de história do divórcio em Portugal (1910-2008), no domínio quer das causas quer dos efeitos do divórcio litigioso: cf. JORGE DUARTE PINHEIRO, O Direito da Família Contemporâneo cit., pp. 620-621. 
do Código Civil de 1966, contemporânea da consagração do princípio da não discriminação dos filhos nascidos fora do casamento, é susceptível de ser entendida como sinal de aceitação da família extramatrimonial, nascida de união de facto.

É também em 1977 que o Código Civil reconhece expressamente direitos emergentes da união de facto, mais precisamente no artigo $2020^{\circ}$, que permitia ao companheiro sobrevivo exigir alimentos da herança do falecido, se ele não os pudesse obter das pessoas indicadas no artigo $2009^{\circ}, \mathrm{n}^{\circ} 1$, alíneas a) a d).

No final do século XX, é publicada a primeira lei portuguesa dedicada especificamente à união de facto, a Lei $n^{\circ}$ 135/99, de 28 de Agosto, prevendo medidas de protecção para os membros de uniões de facto heterossexuais, como as que permitiam a permanência de um deles na habitação comum após a separação ou morte do outro. A Lei $\mathrm{n}^{\circ} 7 / 2001$, de 11 de Maio, alargou às uniões de facto homossexuais as medidas estabelecidas para as uniões de facto heterossexuais e reforçou a protecção do membro sobrevivo da união de facto quanto à casa de morada arrendada. A Lei $\mathrm{n}^{\circ}$ 23/2010, de 30 de Agosto, avançou um pouco mais, mediante a alteração da referida lei de 2001 e de várias disposições do Código Civil.

Actualmente um companheiro beneficia de alguns direitos e prerrogativas que são idênticos ou semelhantes aos que cabem a um cônjuge: o direito a exigir alimentos da herança do companheiro falecido; o direito à transmissão por morte do arrendamento habitacional de que era titular o companheiro falecido; o direito de habitação e o direito de preferência na venda da casa de morada de família pertencente ao companheiro falecido, bem como o direito de uso do recheio da mesma casa; o direito a indemnização por danos não patrimoniais sofridos com a morte do companheiro; e o direito de permanecer na casa de morada comum que pertencia ou estava arrendada, total ou parcialmente, ao outro companheiro, após a cessação da união de facto por vontade de um dos membros. 
III. Hoje, os filhos podem nascer em resultado de relações sexuais ou de procriação medicamente assistida; e estão sujeitos a "responsabilidades parentais" durante a menoridade, o que é compatível com uma certa margem de autodeterminação. Bastante mudou ainda no que toca à adopção, permitida e juridicamente facilitada.

A filiação pode ter na sua origem não só a prática de relações sexuais com pessoa do sexo oposto, mas também técnica de procriação medicamente assistida ou candidatura à adopção.

Em 1977, o Código Civil aceitou a relevância da procriação medicamente assistida, mediante a revogação da norma que até aí a negara $^{18}$; e, três décadas depois, foi publicada a Lei ${ }^{\circ} 32 / 2006$, de 26 de Julho, consagrando um regime geral através do qual se confirma que os beneficiários de técnicas de procriação medicamente assistida são juridicamente pais da criança nascida por causa da aplicação de tais técnicas.

Com o Código Civil de 1966 a adopção voltou a ser admitida no direito português, ainda que de modo tímido ${ }^{19}$. A partir de 1977, sucederam-se as alterações legislativas destinadas a dignificar e a dinamizar o instituto da adopção. Na data em que se conclui este texto, pode adoptar plenamente uma pessoa só ou duas pessoas do sexo diferente que estejam casadas ou que vivam em união de facto há mais de quatro anos (cf. artigo 1979 ${ }^{\circ}, n^{\circ}$ s 1 e 2, do Código Civil, na redacção actual, e artigo $7^{\circ}$ da Lei $n^{\circ} 7 / 2001$, de 11 de Maio), independentemente de terem ou não já filhos ou descendentes.

Desde 1976 que não se tolera a discriminação dos filhos nascidos fora do casamento (artigo $36^{\circ}, \mathrm{n}^{\circ} 4$, da Constituição da República Portuguesa).

\footnotetext{
18 Contida na versão originária do artigo $1799^{\circ}$, citada, supra, na nota 10 .

${ }^{19} \mathrm{Na}$ versão originária do Código, só podiam adoptar plenamente duas pessoas unidas por casamento há mais de dez anos e sem descendentes legítimos (artigo $\left.1981^{\circ}, \mathrm{n}^{\circ} 1\right)$.
} 
Tendo em conta a letra do Código Civil, na redacção de 2008, os pais são titulares de responsabilidades parentais sobre o filho menor (cf., nomeadamente, artigo $1877^{\circ}$ ), o que reflecte a nova visão doutrinária do antigo poder paternal: as situações jurídicas que cabem aos pais do filho menor são enquadradas predominantemente como expressão de um ofício ou função. Além disso, mãe e pai são iguais no exercício de tais situações jurídicas.

Enquanto não atinge a maioridade, agora aos 18 anos de idade (artigo $130^{\circ}$ do Código Civil, na formulação que lhe foi dada em 1977), o filho está sujeito às referidas responsabilidades parentais e obrigado a obedecer aos pais. No entanto, estes, "de acordo com a maturidade dos filhos", devem ter em conta a sua opinião e reconhecer-lhes autonomia (artigo $1878^{\circ}, \mathrm{n}^{\circ} 2$, do Código Civil, após 1977).

\section{O peso da tradição}

I. Não obstante as mudanças que se produziram em 50 anos, há aspectos que permanecem.

Um deles é a preponderância do casamento.

Há, é claro, números que revelam o decréscimo da celebração de casamentos e mesmo da taxa de nupcialidade em Portugal ${ }^{20}$.

Todavia, apesar da concorrência da união de facto, é nítida a preferência dos portugueses por uma organização conjugal da vida íntima ${ }^{21}$.

20 O número de casamentos celebrados em 1965 era 75.483 e em 2013 foi 31.998; a taxa bruta de nupcialidade em 1965 era 8,4 por mil, enquanto em 2013 foi 3,1 (elementos retirados da Base de Dados PORDATA, disponível em http://www. pordata.pt e consultada em 01/03/2015).

21 O confronto relativo entre casamento e união de facto é traçado pelos censos, que se socorrem da contraposição entre "casamento registado" e "casamento não registado". No censo de 2011, o número de "casados sem registo" foi 729.832 , ao passo que o número de "casados com registo" foi 4.902 .026 (Base de Dados PORDATA, disponível em http://www.pordata.pt e consultada em 01/03/2015). Ou 
Daí que a lei invista no Direito Matrimonial, prevendo mais formas de casamento, menos limitações de acesso ao instituto, maior facilidade de extinção do vínculo, e não adira a uma lógica de tendencial equiparação da união de facto ao casamento.

A criação do casamento civil por forma religiosa e a possibilidade do casamento entre pessoas do mesmo sexo são sinais de investimento matrimonial. E a preocupação com o regime do divórcio constitui outro sinal: uma orientação que visa alargar a hipótese de desvinculação seria incompreensível se fosse nula ou escassa a eficácia do casamento. Ora, não é.

$\mathrm{O}$ casamento modifica juridicamente a vida das pessoas que o contraem. Como resulta da versão em vigor do artigo $1577^{\circ}$ do Código Civil, subsiste a imagem do casamento como plena comunhão de vida, isto é, como comunhão íntima, extensa e profunda de duas vidas. Os que se casam adquirem o status ou estado de casado, sujeitando-se a um regime específico, que engloba os chamados deveres dos cônjuges; o nome; a capacidade; a titularidade, administração e disposição dos bens; os contratos; e as dívidas.

A partir do momento em que contraem matrimónio, as pessoas estão reciprocamente vinculadas a deveres inderrogáveis que exigem, nomeadamente, "comunhão de leito, mesa e habitação", socorro, auxílio, contribuição para os encargos de vida familiar e abstenção da prática de actos sexuais com terceiro (cf. artigos $1672^{\circ}, 1674^{\circ}, 1675^{\circ}$, $1676^{\circ}, 1618^{\circ}$ e $1699^{\circ}, \mathrm{n}^{\circ} 1$, alínea b), do Código Civil).

Cada um dos cônjuges pode aditar ao seu nome dois apelidos do outro (artigo $1677^{\circ}$ do Código Civil). E o menor de 16 ou 17 anos que se case adquire plena capacidade de exercício, nos termos do artigo $133^{\circ}$ do Código Civil.

seja, o número de pessoas casadas era cerca de 6,7 vezes superior ao número de pessoas que vivem em união de facto. 
$\mathrm{Na}$ sequência da celebração do casamento, bens que antes pertenciam, ou pertenceriam, a uma pessoa podem pertencer em contitularidade de mão comum aos membros do casal (v.g., bens levados para o casamento, no regime da comunhão geral de bens, nos termos do artigo $1732^{\circ}$ do Código Civil; bens comprados na constância do matrimónio, no regime da comunhão de adquiridos, por força do artigo $1724^{\circ}$, alínea b), do Código Civil); a administração de bens pertencentes exclusivamente a um cônjuge pode caber ao outro e apenas a ele (cf. artigo $1678^{\circ}, n^{\circ} 2$, alíneas e), f) e g), do Código Civil); a alienação de bens pertencentes unicamente a um cônjuge pode carecer do consentimento do outro (cf. artigos $1678^{\circ}, \mathrm{n}^{\circ}$ 3, alínea a), e $1682^{\circ}-\mathrm{A}, \mathrm{n}^{\circ} 1$, do Código Civil); em regra, os contratos de compra e venda entre cônjuges são inválidos (cf. artigo $1714^{\circ}$ do Código Civil) e as doações entre casados são livremente revogáveis pelo doador (cf. artigo $1765^{\circ}$ do Código Civil); por último, as dívidas contraídas por um dos cônjuges podem responsabilizar ambos (cf. artigo $1691^{\circ}, \mathrm{n}^{\circ} 1$, alíneas b), c) e d), do Código Civil).

Em comparação com o casamento, a eficácia civil da união de facto é muito limitada. A lei não impõe aos companheiros deveres análogos aos que vinculam os cônjuges; nem estabelece para aqueles regras semelhantes às dos cônjuges em matéria de nome, capacidade, regimes de bens, administração, disposição, dívidas, validade e revogação de contratos.

As manifestações mais significativas de relevância da ligação entre companheiros referem-se à casa de morada de família e aos alimentos, verificando-se no momento de dissolução da união.

As consequências da dissolução da união de facto estão muito aquém das que decorrem da dissolução do vínculo matrimonial. Havendo casamento, a dissolução extingue a sujeição a um regime inerente ao status ou estado de casado (artigo $1688^{\circ}$ do Código Civil), que se exprime, designadamente, na vinculação aos chamados deveres dos cônjuges e em soluções que se demarcam das 
que são impostas pelas regras comuns em matéria de titularidade de bens, prática de actos de administração e disposição, dívidas e validade dos contratos; na união de facto, a dissolução não implica a cessação de um regime similar, até porque o mesmo nem sequer chegou a vigorar.

$\mathrm{Na}$ hipótese específica de dissolução por morte, o cônjuge sobrevivo tem o direito de suceder como herdeiro legal (artigos 2133 $\mathrm{n}^{\circ} 1$, alíneas a) e b), $\mathrm{n}^{\circ} 3$, e $2157^{\circ}$ do Código Civil); o companheiro sobrevivo não pode ser herdeiro legal do de cuius, beneficiando de meros legados legais que têm por objecto a casa de morada de família e o respectivo recheio (artigo $5^{\circ}$ da Lei $\mathrm{n}^{\circ} 7 / 2001$, de 11 de Maio). No caso de divórcio, o ex-cônjuge que careça de alimentos tem direito a obtê-los do outro (cf. artigos $2009^{\circ}, \mathrm{n}^{\circ} 1$, alínea a), e $2016^{\circ}, n^{\circ} 2$ ), direito que não é conferido ao ex-companheiro da união que cessou por vontade de um dos seus membros.

II. Outro aspecto que permanece é o princípio da monogamia.

Consagrado para o casamento no artigo $1601^{\circ}$, alínea c), do Código Civil $^{22}$, o princípio aplica-se à união de facto.

Apesar de a lei nada dizer expressamente sobre situação em que a mesma pessoa integre simultaneamente duas ou mais uniões de facto, o sistema só admite a relevância jurídica da união de facto única (originária ou sucessiva). Por um lado, o legislador teve o propósito de regular a união de facto tendo em conta a semelhança social da ligação com a união matrimonial, que está sujeita ao princípio da monogamia. Por outro lado, o artigo $1^{\circ}, \mathrm{n}^{\circ} 2$, da Lei $\mathrm{n}^{\circ} 7 / 2001$, de 11 de Maio, usa a expressão "em condições análogas às dos cônjuges" para definir união de facto, expressão que pressupõe uma vivência íntima exclusiva entre dois membros de uma união de facto.

22 À luz do preceito, constitui impedimento dirimente absoluto "o casamento anterior não dissolvido, católico ou civil, ainda que o respectivo assento não tenha sido lavrado no registo do estado civil". 
III. A tradição dita um enquadramento normativo marcado pela biologia e pela biparentalidade heterossexual.

A marca biológica divisa-se no resultado concreto da aplicação da lei da adopção (406 adopções decretadas em 2013) 23; no reconhecimento da necessidade de consagrar instrumentos alternativos à adopção, como o apadrinhamento civil, instituto criado pela Lei $n^{\circ}$ 103/2009, de 11 de Setembro; na irrelevância prática desta figura (sete apadrinhamentos em 2013) ${ }^{24}$; e na determinação de que a procriação medicamente assistida heteróloga só é admissível quando "não possa obter-se gravidez através do recurso a qualquer outra técnica que utilize os gâmetas dos beneficiários" (artigo $10^{\circ}, \mathrm{n}^{\circ} 1$, da Lei $\mathrm{n}^{\circ} 32 / 2006$, de 26 de Julho).

A lógica de biparentalidade está subjacente à não inclusão de pessoas sós, que não sejam membros do casal, entre os beneficiários das técnicas de procriação medicamente assistida (cf. artigo $6^{\circ}, \mathrm{n}^{\circ}$ 1, da Lei ${ }^{\circ} 32 / 2006$, de 26 de Julho), e à proibição da inseminação post mortem (artigo $22^{\circ}, \mathrm{n}^{\circ} 1$, da Lei $\mathrm{n}^{\circ} 32 / 2006$, de 26 de Julho).

A mesma lógica de biparentalidade, conjugada com uma visão biologista, justifica o mecanismo da averiguação oficiosa da maternidade ou paternidade. Sempre que seja lavrado registo de nascimento de menor sem que se aluda à filiação materna e paterna, é desencadeado por iniciativa do Estado um processo com o objectivo de fixar a filiação do menor que esteja em falta (cf. artigos $1808^{\circ}-1813^{\circ}$ e $1864^{\circ}-1867^{\circ}$ do Código Civil).

Mas a biparentalidade que o sistema favorece é a que assenta na diversidade de sexo dos progenitores. Não se permite a duas pessoas do mesmo sexo nem a adopção conjunta (cf. artigo $7^{\circ}$ da Lei $\mathrm{n}^{\circ} 7 / 2001$, de 11 de Maio, a contrario, e artigo $3^{\circ}$ da Lei $n^{\circ}$ 9/2010,

\footnotetext{
23 Base de Dados PORDATA, disponível em http://www.pordata.pt e consultada em $01 / 03 / 2015$.

${ }^{24}$ Cf. informação da Segurança Social, disponível em http://www4.seg-social. pt/documents/10152/13326/Relatorio_CASA_2013, p. 60 (consulta de 01/03/2015).
} 
de 31 de Maio), nem o acesso à procriação medicamente assistida ${ }^{25}$. E tão-pouco se prevê o registo de maternidade em benefício de mulher casada com aquela que deu à $l u z^{26}$.

\section{Mudanças em que sentido?}

O sentido das mudanças no Direito da Família não é propriamente previsível, como decorre da evolução do divórcio no século XX: o divórcio é admitido apenas a partir de 1910; a partir de 1940, é negada a faculdade de divórcio aos que tenham contraído casamento católico; e em 1975 tal faculdade é reconhecida a todos, independentemente da modalidade de casamento.

Contudo, na hipótese de prosseguir a linha evolutiva que se verifica desde 1974-1977, pode esperar-se o reforço da eficácia jurídica da união de facto, a permissão da monoparentalidade por procriação medicamente assistida e a admissibilidade da biparentalidade homossexual.

Por fim, o progresso da ideia de que, não havendo violência ou vulnerabilidade, o conteúdo da relação entre os adultos deve ficar ao dispor dos próprios leva a pensar num futuro em que os efeitos do casamento serão fixados pelos cônjuges por acordo realizado antes ou na constância do matrimónio e na hipótese da relevância

$25 \mathrm{O}$ artigo $6^{\circ}, \mathrm{n}^{\circ} 1$, da Lei $\mathrm{n}^{\circ} 32 / 2006$, de 26 de Julho, verbaliza unicamente a proibição quanto às pessoas que vivam em união de facto homossexual. Todavia, de uma interpretação histórica, sistemática e teleológica do preceito resulta também a interdição da procriação medicamente assistida em benefício de pessoas que integrem uniões conjugais homossexuais (cf. JORGE DUARTE PINHEIRO, O Direito da Família Contemporâneo cit., p. 223).

26 Cf. JORGe DUARTE PInheiro, O Direito da Família Contemporâneo cit., p. 403: ao admitir o casamento entre pessoas do mesmo sexo, a Lei $\mathrm{n}^{\circ}$ 9/2010, de 31 de Maio, não pretendeu inovar na matéria da filiação; por conseguinte, o alcance da presunção pater is est circunscreve-se ao casamento de pessoas de sexo diferente. 
em Portugal do LAT (Living Apart Together) ${ }^{27}$, comunhão de vida a dois em casas separadas, ou mesmo da união poligâmica.

27 Cf. JORGE DUARTE PINHEIRO, O Direito da Família Contemporâneo cit., pp. 692-693. 